\title{
Faktor-Faktor Yang Mempengaruhi Pembiayaan Pada Bank Umum Syariah Devisa Di Indonesia
}

\author{
Umiyati dan Leni Tantri Ana ${ }^{1,2}$ \\ ${ }^{1,2}$ Afiliasi: Fakultas Ekonomi dan Bisnis, UIN Syarif Hidayatullah Jakarta. Email: \\ umiyati@uinjkt.ac.id
}

ABSTRAK. Penelitian ini bertujuan untuk menganalisis pengaruh variabel Dana Pihak Ketiga (DPK), Financing to Deposit Ratio (FDR), Return on Asset (ROA), Non Performing Financing (NPF) dan Inflasi Terhadap Pembiayaan Pada Bank Umum Syariah Devisa di Indonesia. Data yang digunakan dalam penelitian ini adalah data Triwulan dari Maret 2011 sampai Desember 2015. Teknik sampling yang digunakan dalam penelitian ini adalah purposive sampling dengan menggunakan alat analisis regresi linier berganda menggunakan program SPSS versi 20 dan Microsoft Excel 2016. Hasil penelitian menunjukkan secara parsial bahwa Return on Asset (ROA), Performing Financing (NPF) dan Inflasi tidak berpengaruh signifikan terhadap Pembiayaan. Sedangkan Dana Pihak Ketiga (DPK) dan Financing to Deposit Ratio (FDR) berpengaruh signifikan terhadap Pembiayaan. Hasil lainnya menunjukkan nilai Adjusted $R$ Square sebesar 91,3\% yang berarti secara simultan menunjukkan bahwa Jumlah Pembiayaan pada Bank Umum Syariah Devisa dipengaruhi oleh Dana Pihak Ketiga (DPK), Financing to Deposit Ratio (FDR), Return on Asset (ROA), Non Performing Financing (NPF) dan Inflasi Sedangkan sisanya sebesar $8,7 \%$ dipengaruhi oleh variabel lain di luar model.

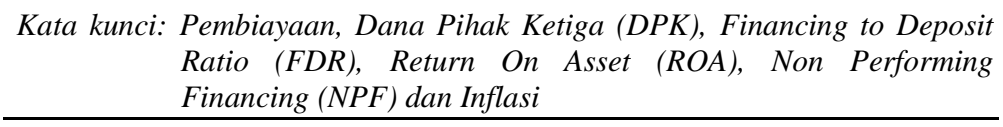

\begin{abstract}
This research aim to analyze the effect of the third-party funds, Financing to Deposit Ratio (FDR), Return on Asset (ROA), Non Performing Financing (NPF) and Inflation against the total of fund at Syariah Banking foreign exchange in Indonesian. The data for assessing this research are acquired quarterly data from March 2011 to December 2015. Technical sampling used in this research is purposive sampling and used multiple linier regression method. Data processing in this research uses SPSS software 20.0 and Microsoft Excel 2016. The results of the analysis indicated that partially, Return on Asset(ROA), Non Performing Financing (NPF) and Inflation has no significant affect to funds. The third-party funds and Financing to Deposit Ratio (FDR) are significant to funds. The amount of the adjust Rsquare is $91,3 \%$. Simultaneously the third-party funds, Financing to Deposit Ratio (FDR), Return on Asset (ROA), Non Performing Financing (NPF) and Inflation have significant affect. While the remaining amount of $8,7 \%$ influenced by other factors that are not included in the study variables.
\end{abstract}

Keywords: $\quad$ The Total of fund, the third-party funds, Financing to Deposit Ratio (FDR), Return on Asset (ROA), Non Performing Financing (NPF) and Inflation 


\section{PENDAHULUAN}

Bank merupakan lembaga keuangan yang sangat penting dalam menjalankan kegiatan perekonomian dan perdagangan di suatu negara. Dalam dunia perbankan terdapat perbankan konvensional dan perbankan syariah. Perbankan syariah sendiri adalah segala sesuatu yang menyangkut tentang Bank Umum Syariah dan Unit Usaha Syariah, mencakup kelembagaan, kegiatan usaha, serta cara dan proses dalam melaksanakan kegiatan usahanya. Perbankan syariah menggunakan prinsip syariah dimana aturan perjanjian didasarkan pada hukum Islam antara bank dan pihak lain untuk penyimpanan dana, pembiayaan kegiatan usaha atau kegiatan lainnya yang sesuai dengan syariah (Yanis dan Priyadi, 2015).

Dalam Perbankan Syariah, pertumbuhan asset Bank Syariah selama periode Juli 2010 sampai Juli 2012 yaitu dari Rp 90.734 Miliar sampai Rp 120.705 Miliar, dengan kenaikan sebesar 88,2\%. Menurut data statistik yang dikeluarkan oleh Bank Indonesia, jumlah Bank Syariah sampai Juli 2012 adalah sebanyak 11 bank. Jumlah tersebut dibagi lagi ke dalam tiga kategori bank, yaitu Bank Uumum Syariah (BUS) Devisa, Bank Umum Syariah (BUS) Non Devisa, dan Bank Campuran.

BUS Devisa adalah bank yang memperoleh surat penunjukan dari Bank Indonesia untuk dapat melakukan kegiatan usaha perbankannya dalam kegiatan valuta asing. Bank yang tergolong ke dalam bank devisa, bisa memberikan layanan yang berkaitan dengan mata uang asing misalnya transfer keluar negeri, transaksi eksport import, jual beli valuta asing, serta jasa-jasa valuta asing lainnya. BUS Devisa merupakan jenis BUS dengan asset terbesar yaitu 40\% dari total asset Perbankan Nasional (Bank Indonesia, "Laporan Keuangan Publikasi Bank Umum Syariah"), karena hal tersebut maka penulis tertarik untuk menjadikan BUS Devisa Indonesia menjadi objek dalam penelitian ini

BUS Non Devisa yaitu bank yang hanya menggunakan satu mata uang (Rupiah) dalam transaksi perbankan, sedangkan Bank campuran adalah bank umum yang didirikan bersama oleh satu atau lebih bank umum yang berkedudukan di Indonesia dan didirikan oleh warga negara Indonesia dengan satu atau lebih bank yang berkedudukan di luar negeri..

Bank Umum Syariah terus mengalami perkembangan, baik dalam pertumbuhan asset maupun penambahan jumlah Bank Umum Syariah (BUS) dari tahun ke tahun. Namun, perkembangan yang dialami bank syariah di Indonesia masih belum optimal, baik dari segi jumlah bank, jumlah kantor, maupun jumlah asetnya. Pada Outlook Perbankan Syariah 2014 tercatat pertumbuhan aset Bank Umum Syariah dan Unit Usaha Syariah per Oktober 2013 yakni 31,8 \% atau mengalami perlambatan pertumbuhan dibandingkan tahun 2012 yaitu sebesar $34,1 \%$.

Otoritas Jasa Keuangan (OJK) menilai, perkembangan bisnis perbankan syariah pada 2015 sedang memasuki masa yang kurang baik. Pertumbuhan aset yang sempat mencapai $49 \%$ pada 2013, tidak bisa terulang lagi pada tahun ini dan harus puas dengan pertumbuhan di angka 7,98 \% pada 
Jurnal Ekonomi dan Perbankan Syariah

Vol. 5. No.1, April 2017: 39-61, ISSN (cet): 2355-1755 | ISSN (online): 2579-6437

\section{| 41}

Juli 2015. Turunnya pertumbuhan perbankan syariah, tidak hanya terjadi dari sisi aset, namun juga pembiayaan dan Dana Pihak Ketiga (DPK). Bahkan pertumbuhan tersebut juga berada jauh di bawah perbankan konvensional. Posisi Juli 2015, pembiayaan hanya tumbuh 5,55 \%, jauh lebih rendah dibanding konvensional yang bertumbuh $8 \%$ (www.beritasatu.com)

Berdasarkan bentuk pembiayaan yang ditawarkan pada bank syariah menurut Suhardjono (2003), yaitu pembiayaan berdasarkan jual beli (ba'i), sewa beli (ijarah waiqtina), bagi hasil (syirkah) dan pembiayaan lainnya. Produk pembiayaan murabahah dan pembiayaan Mudharabah yang dapat dimanfaatkan oleh pelaku usaha terutama untukmembeli barang dan alat (investasi) serta untuk modal kerja (Mudharabah). Macam-macam bentuk pembiayaan yang diberikan bank syariah diharapkan menjadi solusi bagi masalah perekonomian saat ini.

Pembiayaan pada Bank Umum syariah devisa di Indonesia setiap triwulan mengalami perkembangan yang signifikan, terkecuali di tahun 2012 pada bulan Desember mengalami penurunan sebesar Rp 24.174 Milyar. Pembiayaan terus mengalami peningkatan hingga terbesar di tahun 2015 sebesar Rp 35.520 Milyar (Sumber Data Bank Indonesia 2011-2012).

Pembiayaan merupakan penyaluran dana yang paling banyak disalurkan oleh bank kepada masyarakat dan merupakan fungsi utama dari perbankan syariah sebagai lembaga intermediasi, sehingga perlu mendapat perhatian khusus. Oleh karena itu, bank sebagai lembaga keuangan harus memperhatikan berbagai faktor internal maupun eksternal dan aspek apa saja yang dipertimbangkan dalam pengambilan keputusan terhadap masalah pembiayaan atau penyaluran dana pada masyarakat.

Faktor internal perusahaan merupakan salah satu faktor yang mempengaruhi jumlah pembiayaan yang disalurkan. Adapun beberapa rasio keuangan yang sering digunakan untuk menilai kondisi internal perusahaan antara lain; rasio profitabilitas bank yang diwakili oleh Return On Assets (ROA), dan rasio likuiditas bank yang diwakili oleh Financing To DepositRatio (FDR). Disamping rasio keuangan bank tersebut, terdapat faktor internallain yang berpengaruh yaitu Dana Pihak Ketiga (DPK) dan rasio pembiayaan bermasalah Non Performing Financing (NPF). Sedangkan dari faktor eksternal yang dapat mempengaruhi pembiayaan adalah Inflasi.

Faktor internal bank yang merupakan sumber dana terpenting bagi kegiatan operasi bank selain berasal dari milik bank itu sendiri, dan merupakan ukuran keberhasilan bank jika mampu membiayai operasinya dari sumber dana ini yaitu Dana Pihak Ketiga (DPK) (Rodoni, 2009). Dana Pihak Ketiga (DPK) pada BUS Devisa di Indonesia setiap triwulan mengalami kondisi yang fluktuatif di tahun 2011 dan 2012. DPK terendah terjadi pada bulan Juni tahun 2011 yaitu Rp 11.269 Milyar. Pada tahun 2012 mengalami peningkatan di bulan Juni dan penurunan di bulan September dari Rp 23.465 Milyar ke Rp 16.010 Milyar. DPK mulai terjadi peningkatan yang signifikan pada bulan Maret tahun 2013 mencapai Rp 18.080 Milyar. DPK terus mengalami peningkatan di tahun 2014 hingga Rp 31.559 pada bulan 
Desember, dan pada tahun 2015 pembiayaan tertinggi sebesar Rp 32.763 Milyar di bulan Desember (Sumber Data Bank Indonesia 2011-2012).

Berdasarkan penelitian-penelitian sebelumnya berkaitan dengan faktor-faktor yang mempengaruhi pembiayaan, faktor internal bank itu sendiri merupakan salah satu yang dapat mempengaruhi jumlah pembiayaan yang disalurkan. Adapun beberapa rasio keuangan yang sering digunakan untuk menilai kondisi internal perusahaan antara lain; rasio likuiditas bank yang diwakili oleh Financing To Deposit Ratio (FDR) dan rasio profitabilitas bank yang diwakili oleh Return On Assets (ROA). Rasio likuiditas bank, Financingto Deposit Ratio (FDR) merupakan variabel yang konsisten mempengaruhipembiayaan.

FDR adalah rasio perbandingan antara jumlah dana yang disalurkan ke masyarakat dalam bentuk pembiayaan, dengan jumlah dana masyarakat dan modal sendiri yang digunakan (Dendawijaya 2005). FDR yang tinggi menunjukkan bahwa semakin rendahnya kemampuan likuiditas bank yang bersangkutan. FDR menyatakan seberapa jauh kemampuan bank dalam membayar kembali penarikan dana yang dilakukan deposan dengan mengandalkan pembiayaan yang diberikan sebagai sumber likuiditasnya.

Financing to Debt Ratio (FDR) pada BUS Devisa setiap triwulan mengalami kondisi yang fluktuatif. Hal ini dapat dilihat bahwa rasio terendah FDR terjadi pada bulan Desember tahun 2011 yaitu 82,90\%. Di tahun 2012 mengalami peningkatan dan penurunan dari $91,80 \%$ ke $90,60 \%$. FDR tertinggi terjadi pada bulan Juni tahun 2013 mencapai 99,30\%. Tahun 2014 mengalami penurunan dari $97,00 \%$ ke $88,10 \%$, dan pada tahun 2015 mengalami penurunan dari $93,90 \%$ ke $92,20 \%$ (sumber data Bank Indonesia 2011-2012).

Faktor internal kedua adalah rasio profitabilitas, yang diproksi dengan Returnon Asset (ROA) merupakan suatu pengukuran kemampuan manajemen bank dalam memperoleh keuntungan secara keseluruhan. Jika ROA suatu bank semakin besar, maka semakin besar pula tingkat keuntungan yang dicapai bank tersebut dan semakin baik posisi bank tersebut dari segi pengamanan asset (Dendawijaya, 2005). Berdasarkan ketentuan Bank Indonesia, standar ROA yang baik adalah sekitar 1,5\% semakin besar ROA menunjukkan kinerja perusahaan semakin baik, karena return semakin besar.

Return On Asset pada BUS Devisa di Indonesia setiap triwulan mengalami kondisi yang fluktuatif. Tahun 2011 mengalami penurunan, dari 2,20\% hingga 1,59\%. Pada tahun 2012 mengalami peningkatan dan penurunan dari 2,32\% ke 2,27\%. ROA tertinggi terjadi pada bulan Maret tahun 2013 mencapai 2,37\%. Tahun 2014 terjadi penurunan dari 1,40\% ke $0,48 \%$. Dan ROA terendah terjadi pada bulan Maret tahun 2015 yaitu 0,36\% (sumber data Bank Indonesia 2011-2012).

Di samping rasio keuangan bank, adapun faktor internal bank lain yang dapat mempengaruhi pembiayaan yaitu rasio pembiayaan bermasalah NonPerforming Financing (NPF). Kualitas Aktiva dalam hal ini diproksikandengan Non Performing Financing (NPF) dijadikan variabel yang mempengaruhi pembiayaan karena mencerminkan risiko pembiayaan. 
Jurnal Ekonomi dan Perbankan Syariah

Vol. 5. No.1, April 2017: 39-61, ISSN (cet): 2355-1755 | ISSN (online): 2579-6437

| 43

Semakin tinggi rasio ini, menunjukkan kualitas pembiayaan bank syariah semakin buruk. Tingkat kesehatan pembiayaan (NPF) ikut mempengaruhi pencapaian laba bank. Pengelolaan pembiayaan sangat diperlukan oleh bank, mengingat fungsi pembiayaan sebagai penyumbang pendapatan terbesar bagi bank syariah.

Non Performing Financing pada Bank BUS Devisa setiap triwulan mengalami kondisi yang fluktuatif. Pada tahun 2011 mengalami penurunan dari $4,18 \%$ ke 2,92\%. NPF terendah terjadi pada bulan Desember tahun 2012 yaitu 2,40\%. Pada tahun 2013 mengalami peningkatan dari 2,60\% hingga 2,74\%. Pada tahun 2014 mengalami peningkatan dari 3,04\% hingga 4,76\%. Dan NPF tertinggi terjadi pada bulan Maret tahun 2015 mencapai 4,93\%(sumber data Bank Indonesia 2011-2012) .

Dalam pembiayaan, Inflasi dapat juga berpengaruh karena jika terjadi inflasi maka bank sentral akan menaikan bunga kemudian berdampak pada kenaikan bunga oleh bank-bank umum yang akhirnya juga berdampak pada bank syariah, dan jika terjadi inflasi dunia usaha akan mengalami penurunan sebab permintaan agregat akan turun (Saekhu, 2015). Tingkat inflasi berbeda dari satu periode ke periode lainnya, dan berbeda pula dari satu negara ke negara lainnya. Ada kalanya tingkat inflasi rendah, yaitu mencapai di bawah 4-6\%. Tingkat yang moderat mencapai 5-10\%. Inflasi yang sangat serius dapat mencapai tingkat beberapa ratus atau ribu persen dalam setahun (Sukirno, 2007).

Perkembangan tingkat inflasi di Indonesia pada tahun 2011-2012 mengalami fluktuatif. Tingkat inflasi paling tinggi ditunjukkan pada tahun 2013 yaitu sebesar $6,98 \%$. Tingkat inflasi berada posisi terendah yaitu pada tahun 2009 dan 2012 berada pada angka 3,92\%(sumber data Bank Indonesia 2011-2012) .

Dalam hal ini, peneliti mengambil data yang berhubungan dengan faktor internal bank yaitu, Dana Pihak Ketiga (DPK), Financing to Deposit Ratio (FDR), Return On Asset (ROA), Non Performing Financing (NPF) dan dari faktor eksternal yaitu Inflasi. Dilandasi oleh beberapa penelitian terdahulu yang terkait dengan pembiayaan. Salah satunya adalah penelitian Andraeny (2011) menyatakan bahwa Dana Pihak Ketiga (DPK) adalah salah satu faktor yang berpengaruh signifikan terhadap volume pembiayaan berbasis bagi hasil pada perbankan syariah di Indonesia. Hasil dari penelitian tersebut sejalan dengan hasil penelitian Pratami (2011) menunjukkan bahwa Dana Pihak Ketiga (DPK) berpengaruh positif signifikan terhadap pembiayaan. Sedangkan penelitian Maula (2009) menunjukkan hasil yang berbeda yakni Dana Pihak Ketiga (DPK) berpengaruh negatif terhadap pembiayaan murabahah.

Begitu pentingnya pembiayaan bagi bank syariah dan masyarakat, sebagimana kita ketahui manfaat dari pembiayaan syariah yaitu memberikan pembiayaan dengan prinsip syariah yang menerapkan sistem bagi hasil yang tidak memberatkan debitur, dan membantu kaum dhuafa yang tidak tersentuh oleh bank konvensional serta membantu masyarakat ekonomi lemah yang selalu dipermainkan oleh rentenir dengan membantu melalui pendanaan 
untuk usaha yang dilakukan. Oleh sebab itu, penulis termotivasi untuk melakukan penelitian untuk mengetahui faktor-faktor apa saja yang dapat mempengaruhi pembiayaan.

\section{TELAAH TEORITIS}

\subsection{PEMBIAYAAN BANK SYARIAH}

Menurut Undang-Undang Nomor 21 Tahun 2008 tentang Perbankan (Pasal 1) disebutkan bahwa, "Pembiayaan berdasarkan prinsip syariah adalah penyediaan uang/tagihan yang dapat dipersamakan dengan itu, berdasarkan persetujuan atau kesepakatan antara bank dengan pihak lain yang mewajibkan pihak yang dibiayai untuk mengembalikan uang/tagihan tersebut setelah jangka waktu tertentu dengan imbalan bagi hasil”.

Pada pasal 1 UU No. 21/2008 mendefinisikan bahwa prinsip syariah adalah prinsip hukum Islam dalam kegiatan perbankan berdasarkan fatwa yang dikeluarkan oleh lembaga yang memiliki kewenangan dalam penetapan fatwa di bidang syariah, dengan kata lain prinsip syariah adalah aturan perjanjian berdasarkan hukum Islam antara bank dan pihak lain untuk penyimpanan dana dan atau pembiayaan kegiatan usaha, atau kegiatan lainnya yang dinyatakan sesuai syariah, antara lain pembiayaan berdasarkan prinsip bagi hasil (Mudharabah), pembiayaan berdasarkan prinsip penyertaan modal (musyarakah), prinsip jual beli barang dengan memperoleh keuntungan (murabahah), atau pembiayaan barang modal berdasarkan prinsip sewa murni tanpa pilihan (ijarah), atau dengan adanya pilihan pemindahan kepemilikan atas barang yang disewa dari pihak bank oleh pihak lain (ijarah wa iqtina).

Menurut Muhammad (2002), pembiayaan secara luas berarti financing atau pembelanjaan, yaitu pendanaan yang dikeluarkan untukmendukung investasi yang telah direncanakan, baik dilakukan sendiri maupun dijalankan oleh orang lain. Dalam arti sempit, pembiayaan dipakai untuk mendefinisikan pendanaan yang dilakukan oleh lembaga pembiayaan, seperti bank Syarieeah, kepada nasabah.

Dalam menyalurkan dana pada nasabah, secara garis besar produk pembiayaan syariah terbagi kedalam tiga kategori yang dibedakan berdasarkan tujuan penggunaannya yaitu: (1) Transaksi pembiayaan yang ditujukan untuk memiliki barang dilakukan dengan prinsip jual beli; (2) Transaksi pembiayaan yang ditujukan untuk mendapatkan jasa dilakukan dengan prinsip sewa; (3) Transaksi pembiayaan untuk usaha kerjasama yang ditujukan guna mendapatkan sekaligus barang dan jasa, dengan prinsip bagi hasil.

Pada kategori ke-1 (pertama) dan ke-2 (kedua), tingkat keuntungan bank ditentukan di depan dan menjadi bagian harta atas barang atau jasa yang dijual. Produk yang termasuk dalam kelompok ini adalah produk yang menggunakan prinsip jual-beli seperti Murabahah, Salam, dan Ishtishna serta produk yang menggunakan prinsip sewa Ijarah. Pada kategori ke-3 (ketiga), 
Jurnal Ekonomi dan Perbankan Syariah

Vol. 5. No.1, April 2017: 39-61, ISSN (cet): 2355-1755 | ISSN (online): 2579-6437

45

tingkat keuntungan bank ditentukan dari besarnya keuntungan usaha sesuai dengan prinsip bagi hasil. Pada produk bagi hasil keuntungan ditentukan oeh nisbah bagi hasil yang disepakati di muka. Produk perbankan yang termasuk ke dalam kelompok ini adalah Musyarakah dan Mudharabah (Rodoni, 2009).

\subsection{FAKTOR-FAKTOR YANG BERHUBUNGAN DENGAN PEMBIAYAAN}

\subsubsection{Dana Pihak Ketiga (DPK)}

Dana Pihak Ketiga adalah dana yang diperoleh dari masyarakat, dalam arti masyarakat sebagai individu, perusahaan, pemerintah, rumah tangga, koperasi, yayasan, dan lain-lain baik dalam mata uang rupiah maupun dalam valuta asing. Pada sebagian besar atau setiap bank, dana masyarakat ini umumnya merupakan dana terbesar yang dimiliki. Hal ini sesuai dengan fungsi bank sebagai penghimpun dana dari masyarakat (Heithzal Rivai, dkk, 2007).

Berdasarkan prinsip tersebut Bank syariah dapat menarik Dana Pihak Ketiga (DPK) atau masyarakat dalam bentuk (Zainul Arifin, 2006):

1. Titipan (wadiah) simpanan yang dijamin keamanan dan pengembaliannya (guaranteed deposit) tetapi tanpa memperoleh imbalan atau keuntungan..

2. Partisipasi modal berbagi hasil dan berbagi resiko (nonguaranteed account) untuk investasi umum (general investment account) Mudharabah mutlaqah) di mana bank akan membayarbagian keuntungan secara proporsional dengan porofolio yang didanai dengan modal tersebut.

3. Investasi khusus (special investment account/Mudharabahmuqayyadah) di mana bank bertindak sebagai manajer investasiuntuk memperoleh fee. Jadi bank tidak ikut berinvestasi sedangkan investor sepenuhnya mengambil resiko atas investasi.

\subsubsection{Financing to Deposit Ratio (FDR)}

Financing to Deposit Ratio (FDR) adalah perbandingan antarapembiayaan yang diberikan oleh bank dengan Dana Pihak Ketiga yang berhasil dikerahkan oleh bank (Muhammad, 2005).

Rasio FDR yang analog dengan Loan to Deposit Ratio (LDR) pada bank konvensional adalah rasio yang digunakan untuk mengukur seberapa jauh kemampuan bank dalam membayar kembali penarikan dana yang dilakukan deposan dengan mengandalkan pembiayaan yang diberikan sebagai sumber likuiditasnya (Dendawijaya, 2003). Standar yang ditetapkan Bank Indonesia untuk rasio FDR adalah 90 - 110\%.

\subsubsection{Return On Assets (ROA)}

Return On Assets (ROA) merupakan rasio yang digunakanuntuk mengukur kemampuan manajemen bank dalam memperoleh laba secara keseluruhan 
(Dendawijaya, 2003). Semakin besar ROA, semakin besar pula tingkat keuntungan yang dicapai bank tersebut dan menunjukkan kinerja perusahaan yang semakin baik.

ROA merupakan rasio antara laba sebelum pajak terhadap rata-rata total aset. Semakin besar ROA, semakin besar pula tingkat keuntungan yang dicapai bank (Almilia, 2005).

\subsubsection{Non Performing Financing (NPF)}

Non Performing Financing (NPF) yang analog dengan Non Performing Loan (NPL) pada bank konvensional merupakan rasiokeuangan yang bekaitan dengan risiko kredit. NPF menunjukan kemampuan manajemen bank dalam mengelola pembiayaan bermasalah yang diberikan oleh bank. Sehingga semakin tinggi rasio ini maka akan semakin semakin buruk kualitas pembiayaan bank yang menyebabkan jumlah pembiayaan bermasalah semakin besar maka kemungkinan suatu bank dalam kondisi bermasalah semakin besar.

Pembiayaan dalam hal ini adalah pembiayaan yang diberikan kepada pihak ketiga tidak termasuk pembiayaan kepada bank lain. Pembiayaan bermasalah adalah pembiayaan dengan kualitas kurang lancar, diragukan dan macet (Almilia, 2005). Standar yang ditetapkan Bank Indonesia untuk rasio NPF adalah $3.52 \%$.

\subsubsection{Inflasi}

Inflasi adalah proses meningkatnya harga-harga secara umum dan terusmenerus (continue) berkaitan dengan mekanisme pasar yang dapat disebabkan oleh berbagai faktor, antara lain, konsumsi masyarakat yang meningkat, berlebihnya likuiditas di pasar yang memicu konsumsi, sampai termasuk juga akibat adanya ketidaklancaran distribusi barang (Firaldi, 2003). Dengan kata lain, inflasi merupakan proses menurunnya nilai mata uang secara kontinu.

Inflasi adalah proses dari suatu peristiwa, bukan tinggi-rendahnya tingkat harga. Artinya, tingkat harga yang dianggap tinggi belum tentu menunjukan inflasi. Inflasi adalah indikator untuk melihat tingkat perubahan, dan dianggap terjadi jika proses kenaikan harga berlangsung secara terusmenerus dan saling pengaruh-memengaruhi. Istilah inflasi juga digunakan untuk mengartikan peningkatan persediaan uang yang kadangkala dilihat sebagai penyebab meningkatnya harga.

\subsection{BANK UMUM SYARIAH DEVISA}

Dalam Pasal 1 Undang-Undang No. 21 Tahun 2008, disebutkan bahwa bank adalah badan usaha yang menghimpun dana masyarakat dalam bentuk simpanan dan menyalurkannya kepada masyarakat dalam bentuk kredit dan atau bentuk-bentuk lainnya dalam rangka meningkatkan taraf hidup masyarakat banyak. Bank terdiri atas dua jenis, yaitu bank konvensional dan bank syariah. 
Jurnal Ekonomi dan Perbankan Syariah

Vol. 5. No.1, April 2017: 39-61, ISSN (cet): 2355-1755 | ISSN (online): 2579-6437

47

Bank konvensional adalah bank yang menjalankan kegiatan usahanya tidak berdasarkan prinsip syariah yang terdiri atas bank umum konvensional dan bank perkreditan rakyat. Bank syariah adalah bank yang menjalankan kegiatan usahanya berdasarkan prinsip syariah yang terdiri atas Bank Umum Syariah (BUS) dan Bank Pembiayaan Rakyat Syariah (BPRS). Prinsip syariah adalah prinsip hukum islam dalam kegiatan perbankan berdasarkan fatwa yang dikeluarkan oleh lembaga yang memiliki kewenangan dalam penetapan fatwa di bidang syariah.

Klasifikasi bank menurut transaksi valuta asing, bank di bagi menjadi Bank Devisa yaitu bank yang menggunakan lebih dari satu mata uang dalam transaksi perbankan, dan Bank Non Devisa yaitu bank yang hanya menggunakan satu mata uang (Rupiah) dalam transaksi perbankan. Ada dua jenis bank yang dikelompokan berdasarkan kapasitas kegiatannya dalam bentuk valuta asing (Valas) yaitu kelompok bank yang dinamakan bank devisa dan bank non devisa baik untuk bank konvensional ataupun bank syariah.

Bank devisa adalah bank yang memperoleh surat penunjukan dari Bank Indonesia untuk dapat melakukan kegiatan usaha perbankannya dalam kegiatan valuta asing. Bank yang tergolong kedalam bank devisa, bisa memberikan layanan yang berkaitan dengan mata uang asing misalnya transfer keluar negeri, transaksi eksport import, jual beli valuta asing, serta jasa-jasa valuta asing lainnya.

Syarat-syarat yang harus dipenuhi sebelum suatu bank non devisa dapat diberikan izin untuk menjadi bank devisa, antara lain:

1. CAR (Capital Adequacy Ratio) minimum dalam bulan terakhir $8 \%$,

2. Tingkat kesehatan selama 24 bulan terakhir berturut tergolong sehat,

3. Modal disetor minimal Rp.150 Miliar, dan

4. Bank telah melakukan persiapan untuk melaksanakan kegiatan sebagai Bank Umum Devisa meliputi organisasi, sumber dayamanusia, pedoman operasional kegiatan devisa, dan sistem administrasi serta pengawasannya.

Perbedaan antara bank devisa dan bank non devisa yaitu bahwa bank non devisa tidak bisa melakukan kegiatan usaha yang berhubungan dengan kegiatan usaha valuta asing, sedangkan bank devisa dapat melakukan kegiatan yang berhubungan dengan valuta asing. Bank Syariah di Indonesia yang tergolong bank devisa sesuai dengan SK yang dikeluarkan Bank Indonesia pada masing-masing bank adalah:

1. PT. BNI Syariah (SK GBI No. 12/41/KEP.GBI/2010, Tgl. 09 Juli 2010).

2. PT. Bank Muamalat Indonesia (SK.DIR.BI No. 7/76/KEP/DIR, Tgl. 27 Oktober 1994). 
48 | Umiyati\&Ana:Faktor-Faktor Yang Mempengaruhi Pembiayaan...

3. PT. Bank Syariah Mandiri (SK DpG BI BI No. 4/3/Kep/DpG//2002, Tgl. 18 Maret 2002).

4. PT. Bank Syariah Mega Indonesia (SK DGS BI No.3/1/KEP.DGS/2001, Tgl. 31 Januari 2001).

\subsection{PERUMUSAN HIPOTESIS PENELITIAN}

H01 : Dana Pihak Ketiga (DPK), Financing to Deposit Ratio (FDR), Return on Asset (ROA), Non Performing Financing (NPF) dan Inflasi tidak berpengaruh signifikan secara simultan terhadap pembiayaan pada Bank Umum Syariah Devisa di Indonesia.

Ha1 : Dana Pihak Ketiga (DPK), Financing to Deposit Ratio (FDR), Return on Asset (ROA), Non Performing Financing (NPF) dan Inflasi berpengaruh signifikan secara simultan terhadap pembiayaan pada Bank Umum Syariah Devisa di Indonesia.

H02 : Dana Pihak Ketiga (DPK), tidak berpengaruh signifikan terhadap pembiayaan pada Bank Umum Syariah Devisa di Indonesia.

Ha2: Dana Pihak Ketiga (DPK) berpengaruh signifikan terhadap pembiayaan pada Bank Umum Syariah Devisa di Indonesia.

H03 : Financing tto Deposit Ratio (FDR) tidak berpengaruh signifikan terhadap pembiayaan pada Bank Umum Syariah Devisa di Indonesia.

Ha3: Financing to Deposit Ratio (FDR) berpengaruh signifikant terhadap pembiayaan pada Bank Umum Syariah Devisa di Indonesia.

H04 : Return on Asset (ROA) tidak berpengaruh signifikan terhadap pembiayaan pada Bank Umum Syariah Devisa di Indonesia.

Ha4 : Return on Asset (ROA) berpengaruh signifikan terhadap pembiayaan pada Bank Umum Syariah Devisa di Indonesia.

H05: Non Performing Financing (NPF) tidak berpengaruh signifikan terhadap pembiayaan pada Bank Umum Syariah Devisa di Indonesia.

Ha5 : Non Performing Financing (NPF) berpengaruh signifikan terhadap pembiayaan pada Bank Umum Syariah Devisa di Indonesia.

H06 : Inflasi tidak berpengaruh berpengaruh signifikan terhadap pembiayaan pada Bank Umum Syariah Devisa di Indonesia.

Ha6 : Inflasi berpengaruh berpengaruh signifikan terhadap pembiayaan pada Bank Umum Syariah Devisa di Indonesia.

\section{METODE PENELITIAN}

Penelitian ini termasuk ke dalam penelitian kausal komparatif yaitu tipe penelitian dengan karakteristik masalah berupa hubungan sebab-akibat antara 
Jurnal Ekonomi dan Perbankan Syariah

Vol. 5. No.1, April 2017: 39-61, ISSN (cet): 2355-1755 | ISSN (online): 2579-6437

dua variabel atau lebih. Peneliti melakukan pengamatan terhadap konsekuensi-konsekuensi yang timbul dan menelusuri kembali fakta yang secara masuk akal sebagai faktor-faktor penyebabnya (Indriantoro dan Supomo, 2011). Berdasarkan tingkat ekplanasinya penelitian ini termasuk jenis penelitian assosiatif yaitu jenis penelitian untuk mencari pengaruh atau hubungan antara dua variabel atau lebih (sugiyono,2009)

Penelitian ini bertujuan untuk menguji variabel Dana Pihak Ketiga (DPK), Financing to Deposit Ratio (FDR), Return On Asset (ROA), Non Performing Financing (NPF), dan Inflasi terhadap Pembiayan pada Bank Umum Syariah Devisa di Indonesia. Populasi dalam penelitian ini adalah Bank Umum Syariah Devisa yang berada di Indonesia selama periode Januari 2011 - Juni 2015.

Metode penentuan sampel yang digunakan dalam penelitian ini adalah Purposive Sampling. Menurut Siregar (2011) Purposive Sampling adalah teknik pemilihan sampel berdasarkan pada kriteria-kriteria tertentu. Sampel untuk penelitian ini adalah Bank Umum Syariah Devisa yang terdaftar di Bank Indonesia periode 2011-2015, dengan pertimbangan sebagai berikut:

1. Bank Umum Syariah Devisa yang terdaftar di Bank Indonesia periode 2011-2015.

2. Bank Umum Syariah Devisa yang menerbitkan laporan keuangan triwulan selama lima tahun berturut-turut, yaitu dari tahun 2011 sampai dengan tahun 2015.

3. Bank Umum Syariah tidak keluar (delisting) dari kategori Bank Umum Syariah Devisa yang terdaftar di Bank Indonesia periode 2011-2015.

4. Laporan keuangan triwulan Bank Umum Syariah Devisa memiliki data-data yang dibutuhkan dalam penelitian.

Berdasarkan kriteria tersebut, maka diperoleh tiga Bank Umum Syariah Devisa yaitu Bank Syariah Mandiri, Bank Muamalat Indonesia, dan Bank Negara Indonesia Syariah. Data yang digunakan penelitian ini merupakan data sekunder, data tersebut diperoleh langsung dari Laporan situs resmi Bank Indonesia yaitu laporan keuangan triwulan Bank Umum Syariah Devisa periode tahun 2011 - 2015. Metode yang digunakan dalam pengumpulan data untuk melakukan penelitian ini adalah field research, library research, dan internet research.

Penelitian ini menggunakan metode analisis regresi linier berganda dengan menggunakan program komputer yaitu Software Statistical Package for the Social Sciences (SPSS) versi 20 dan Microsoft Excel 2016. Metode yang digunakan dalam menganalisis data pada penelitian ini adalah Uji Asumsi Klasik dan Uji Hipotesis. Uji Asumsi klasik dilakukan untuk mendeteksi apakah terdapat normalitas, multikolinieritas, heterokedastisitas dan autokorelasi. Sedangkan Uji Hipotesis dalam pengujian ini menggunakan 
Uji Statistik meliputi Uji t, Uji F dan Uji Koefisien Determinasi (Adjusted R Square).

Variabel dependen pada penelitian ini adalah pembiayaan, pembiayaan merupakan salah satu tugas pokok bank syariah, yaitu pemberian fasilitas penyediaan dana untuk memenuhi kebutuhan pihakpihak yang membutuhkan pembiayaan. Sedangkan variabel independen yang dipilih berdasarkan studi literatur berbagai penelitian terdahulu yang menunjukkan hasil yang berbeda dan adanya inkonsistensi dari kondisi empiris terhadap teori yang ada, variabel independen yang dimaksud yaitu Dana Pihak Ketiga (DPK), Financing to Deposit Ratio (FDR), Return On Asset (ROA), Non Performing Financing (NPF), dan Inflasi. Berikut ini definisi operasional variabel yang digunakan dalam penelitian:

Tabel 1. Ringkasan Definisi Operasional Variabel

\begin{tabular}{|c|c|c|c|c|}
\hline No & Variabel & Pengukuran Variabel & $\begin{array}{c}\text { Skala } \\
\text { Pengukuran }\end{array}$ & Sumber \\
\hline 1 & $\begin{array}{l}\text { Pembiayaan } \\
(\mathrm{Y})\end{array}$ & $\begin{array}{l}\text { Pembiayaan=Piutang } \\
\text { Murabahah+ Piutang } \\
\text { Salam+ Piutang Istishna+ } \\
\text { Piutang Qord + Ijarah + } \\
\text { pembiayaan } \\
\text { mudaharabah+pembiayaan } \\
\text { musyarakah }\end{array}$ & Nominal & $\begin{array}{l}\text { Ahamd } \\
\text { Rodoni } \\
(2009)\end{array}$ \\
\hline 2 & $\begin{array}{l}\text { Dana Pihak } \\
\text { Ketiga } \\
(\mathrm{DPK})(\mathrm{X} 1)\end{array}$ & $\begin{aligned} \text { DPK } & =\text { Giro+Deposito } \\
& + \text { Tabungan }\end{aligned}$ & Nominal & $\begin{array}{c}\text { Heitzal } \\
\text { Rivai,dkk } \\
(2007)\end{array}$ \\
\hline 3 & $\begin{array}{l}\text { Financing } \\
\text { to Deposit } \\
\text { Ratio } \\
\text { (FDR) (X2) }\end{array}$ & $\begin{array}{l}\text { Total Pembiayaan x } 100 \% \\
\text { Dana Pihak Ketiga }\end{array}$ & Rasio & $\begin{array}{c}\text { Dendawijaya } \\
(2003)\end{array}$ \\
\hline 4 & $\begin{array}{l}\text { Return On } \\
\text { Asset } \\
\text { (ROA) } \\
\text { (X3) }\end{array}$ & $\begin{array}{l}\text { Laba sblm Pajak x100\% } \\
\text { Total Aset }\end{array}$ & Rasio & $\begin{array}{l}\text { Dendawijaya } \\
(2003)\end{array}$ \\
\hline 5 & $\begin{array}{l}\text { Non } \\
\text { Performing } \\
\text { Financing } \\
\text { (NPF) (X4) }\end{array}$ & $\begin{array}{l}\text { Pemby. bermasalah } \\
\text { x100\% } \\
\text { Total Pembiayaan }\end{array}$ & Rasio & $\begin{array}{l}\text { Fitri Zulfiah } \\
\quad(2013)\end{array}$ \\
\hline 6 & Inflasi (X5) & $\begin{array}{l}\text { Tingkat Inflasi pada } \\
\text { periode }(\mathrm{t}-1)\end{array}$ & Rasio & $\begin{array}{l}\text { Firaldi } \\
(2013)\end{array}$ \\
\hline
\end{tabular}


Jurnal Ekonomi dan Perbankan Syariah

Vol. 5. No.1, April 2017: 39-61, ISSN (cet): 2355-1755 | ISSN (online): 2579-6437

| 51

\section{PEMBAHASAN}

Bank Umum Syariah yang terdaftar di Bank Indonesia pada periode 2011 hingga 2015 merupakan populasi dalam penelitian ini dan Bank Umum Syariah Devisa merupakan sampel dari penelitian ini. Dari pertimbangan tersebut didapatkan sampel sebanyak tiga Bank Umum Syariah Devisa dengan total 60 data observasi

Hipotesis dalam penelitian ini diuji dengan menggunakan regresi linier berganda. Tujuannya untuk memperoleh gambaran secara menyeluruh mengenai pengaruh variabel independen Dana Pihak Ketiga (DPK), Financing to Deposit Ratio (FDR), Return On Asset (ROA), NonPerforming Financing (NPF) dan Inflasi terhadap variabel dependenyaitu Pembiayaan pada Bank Umum Syariah Devisa di Indonesia.

\subsection{HASIL UJI ASUMSI KLASIK}

\subsubsection{Hasil Uji Normalitas}

Dalam penelitian ini pengujian uji normalitas dilakukan dengan menggunakan metode uji non-parametrik Kolmogorov-Smirnov (K-S). Dasar pengambilan keputusan pada uji $\mathrm{K}-\mathrm{S}$ ini adalah dengan melihat nilai probabilitas signifikansi data residual. Jika angka probabilitas kurang dari 0,05 maka variabel ini tidak berdistribusi secara normal. Sebaliknya, bila angka probabilitas di atas 0,05 maka $\mathrm{Ha}$ ditolak yang berarti variabel terdistribusi secara normal (Ghozali, 2011).

Tabel 2. Uji Normalitas Kolmogorov-Smirnov

\section{One-Sample Kolmogorov-Smirnov Test}

\begin{tabular}{lr}
\hline & Unstandardized Residual \\
\hline $\mathrm{N}$ & 60 \\
Mean & $0 \mathrm{E}-7$ \\
Normal Parameters ${ }^{\mathrm{a}, \mathrm{b}}$ & \\
Std. Deviation & 5,05932587 \\
Absolute &, 077 \\
Most Extreme Differences & Positive \\
Negative &, 077 \\
Kolmogorov-Smirnov Z &,- 074 \\
Asymp. Sig. (2-tailed) &, 599 \\
\hline
\end{tabular}

a. Test distribution is Normal.

b. Calculated from data.

Berdasarkan tabel 2 diatas, hasil uji Kolmogorov-Smirnov (K-S) menunjukan nilai sebesar 0,866 yang berarti bahwa data terdistribusi secara normal. Hal ini dapat terlihat karena nilai probabilitas sebesar 0,866 jauh lebih besar dari 0,05. Sehingga model penelitian ini memenuhi uji asumsi klasik normalitas.

\subsubsection{Hasil Uji Multikolonieritas}


Uji multikolinieritas bertujuan untuk menguji apakah adanya korelasi antar variabel bebas (independen) dalam model regresi. Untuk mendeteksi adanya masalah multikolinieritas dalam penelitian ini dengan menggunakan Nilai Tolerance dan VIF (VarianceInflation Factor). Pada tabel 3 berikut ini, disajikan hasil uji multikolinieritas:

Tabel 3. Uji Multikolinieritas

Coefficients $^{\mathrm{a}}$

\begin{tabular}{lccc}
\hline & Model & \multicolumn{2}{c}{ Collinearity Statistics } \\
\cline { 2 - 3 } & \multicolumn{2}{c}{ Tolerance } & VIF \\
\hline DPK &, 709 & 1,410 \\
FDR &, 759 & 1,318 \\
ROA &, 631 & 1,584 \\
NPF &, 440 & 2,274 \\
INFLASI &, 879 & 1,138 \\
\hline
\end{tabular}

a.Dependent Variable: Pembiayaan

Berdasarkan output pada Coefficients dalam tabel 3 di atas, menunjukan hasil uji multikolinieritas dengan nilai Tolerance berkisar antara 0,440 - 0,879 (>0,10). Sedangkan nilai VarianceInflation Factor (VIF) berkisar antara 1,138-2,274 $(<10)$, dari hasiltersebut dapat disimpulkan bahwa dalam model penelitian ini tidak terjadi masalah multikolinieritas.

\subsubsection{Hasil Uji Heteroskedastisitas}

Dalam penelitian ini, uji heteroskedastisitas dengan menggunakan uji glejser. Uji glejser mengusulkan untuk meregres nilai absolut residual terhadap variabel independen (Gujarati, 2003). Jika variabel independen signifikan secara statistik mempengaruhi variabel dependen, maka ada indikasi terjadi heteroskedastisitas (probabilitas signifikansi tingkat kepercayaan 5\%) (Ghozali, 2011). Pada tabel 4 berikut ini hasil uji glejser.

Tabel 4. Uji Glejser

Coefficients $^{\mathrm{a}}$

\begin{tabular}{|c|c|c|c|c|c|}
\hline \multirow[t]{2}{*}{ Model } & \multicolumn{2}{|c|}{$\begin{array}{l}\text { Unstandardized } \\
\text { Coefficients }\end{array}$} & \multirow{2}{*}{$\begin{array}{c}\begin{array}{c}\text { Standardiz } \\
\text { edCoeffici } \\
\text { ents }\end{array} \\
\text { Beta }\end{array}$} & \multirow[t]{2}{*}{$\mathrm{t}$} & \multirow[t]{2}{*}{ Sig. } \\
\hline & B & $\begin{array}{l}\text { Std } \\
\text { Error }\end{array}$ & & & \\
\hline (Constant) & 2,026 & 6,111 & & ,331 & ,742 \\
\hline DPK &,- 042 & ,022 &,- 289 & $-1,916$ & ,061 \\
\hline FDR &, 056 & ,060 &, 135 & ,922 & ,360 \\
\hline \multicolumn{6}{|l|}{1} \\
\hline ROA & $-1,105$ & 699 &,- 253 & $-1,581$ & , 120 \\
\hline NPF & , 140 & ,452 & ,059 & ,308 & ,759 \\
\hline INFLASI &,- 111 & ,249 &,- 060 &,- 445 & ,658 \\
\hline
\end{tabular}

a. Dependent Variable: Pembiayaan 
Jurnal Ekonomi dan Perbankan Syariah

Vol. 5. No.1, April 2017: 39-61, ISSN (cet): 2355-1755 | ISSN (online): 2579-6437

53

Dari hasil uji glejser tersebut, semua variabel independen menunjukan angka signifikansi di atas 0,05 yang berarti bahwa dalam persamaan regresi tersebut tidak terjadi heteroskedastisitas.

\subsubsection{Hasil uji autokorelasi}

Pada penelitian ini menggunakan Runs Test dalam menilai ada tidaknya masalah autokorelasi dalam model penelitian ini, hasil pengujian ini dapat dilihat dari nilai Asymp. Sig. (2-tailed) di mana nilai signifikansinya harus lebih besar dari 0,05 (Ghozali, 2011). Pada tabel 5 berikut merupakan hasil uji autokorelasi dengan menggunakan Runstest:

Tabel 5. Hasil Uji Autokorelasi (Runs Test) Unstandardized Residual

Test Value ${ }^{\mathrm{a}}$ $-, 64741$

Cases $<$ Test Value 30

Cases $>=$ Test Value 30

Total Cases 60

Number of Runs

$\mathrm{Z}$

Asymp. Sig. (2-tailed)

a. Median

Hasil pengujian ini dapat dilihat dari nilai Asymp. Sig. (2-tailed) di mana nilai signifikansinya harus lebih besar dari 0,05. Dapat kita lihat di atas Asymp. Sig. (2-tailed) sebesar 0,118 maka tidak ada masalah autokorelasi.

\subsection{HASIL UJI HIPOTESIS}

\subsubsection{Hasil Uji koefisien determinasi}

Adapun hasil uji koefisien Adjusted $R$ Square disajikan pada tabel 6 di bawah ini:

Tabel 6. Uji Adjusted R Square (R2adj)

\begin{tabular}{rrrrr}
\hline Model & R & R Square & $\begin{array}{l}\text { Adjusted } \\
\text { RSquare }\end{array}$ & $\begin{array}{l}\text { Std. Error of } \\
\text { theEstimate }\end{array}$ \\
\hline &, $960^{\text {a }}$ &, 921 &, 913 & 5,28837 \\
\hline
\end{tabular}

a. Predictors: (Constant), INFLASI, NPF, FDR, DPK, ROA

b. Dependent Variable: Pembiayaan 
Tabel 6 tersebut menunjukkan nilai Adjusted $R$ Square sebesar 0,913, hal ini berarti bahwa 91,3\% variabel Pembiayaan dapat dijelaskan oleh Dana Pihak Ketiga (DPK), Financing to Deposit Ratio (FDR), Return On Asset (ROA), Non Performing Financing (NPF) dan Inflasi. Sedangkan sisanya yaitu sebesar $8,7 \%$ dijelaskan oleh faktor-faktor lain yang tidak diteliti dalam penelitian ini.

\subsubsection{Hasil Uji Signifikansi Simultan (Uji Statistik F)}

Pada tabel 7 berikut ini disajikan Uji statisik $F$ untuk variabel Pembiayaan,DPK, FDR,ROA,NPF dan Inflasi, sebagai berikut:

Tabel 7. Uji Statistik F (Simultan)

\begin{tabular}{rlrrrrr}
\multicolumn{6}{c}{ MNOVA $^{\mathrm{a}}$} \\
\hline Model & $\begin{array}{c}\text { Sum } \\
\text { ofSquare } \\
\mathrm{S}\end{array}$ & df & $\begin{array}{c}\text { Mean } \\
\text { Square }\end{array}$ & F & Sig. \\
\hline \multirow{2}{*}{1} & Regression & 17538,338 & 5 & 3507,668 & 125,422 &, $000^{\mathrm{b}}$ \\
& Residual & 1510,210 & 54 & 27,967 & & \\
& Total & 19048,548 & 59 & & & \\
\hline
\end{tabular}

a. Dependent Variable: Pembiayaan

b. Predictors: (Constant), Inflasi, NPF, FDR, DPK, ROA

Berdasarkan tabel 7 di atas, nilai $F$ hitung sebesar 125,422 dengan nilai $\mathrm{F}$ tabel $\mathrm{df}: \alpha,(\mathrm{k}-1),(\mathrm{n}-\mathrm{k})$ atau $0,05,(5-1),(60-5)=2,54$ dan nilai signifikansi 0,000. Dengan demikian karena nilai Fhitung > Ftabel $(125,422$ $>2,54)$ dan nilai signifikansi lebih kecil dari $0,05(0,000<0,05)$ maka $\mathrm{H}_{1}$ ditolak atau $\mathrm{Ha}_{1}$ diterima, sehingga mendukung hipotesis 1 yaitu Dana Pihak Ketiga (DPK), Financing tto Deposit Ratio (FDR), Return on Asset (ROA), Non Performing Financing (NPF) dan Inflasi berpengaruh signifikan secara simultanterhadap pembiayaan pada Bank Umum Syariah Devisa di Indonesia.

\subsubsection{Uji Signifikansi Parameter Individual (Uji t Statistik)}

Tabel 8 menunjukkan bahwa hasil uji statistik $t$ untuk variabel Pembiayaan,DPK, FDR,ROA,NPF dan Inflasi, sebagai berikut :

Tabel 8. Uji Statistik t (Parsial)

Coefficients $^{\mathrm{a}}$

\begin{tabular}{|c|c|c|c|c|c|c|c|}
\hline \multirow[t]{2}{*}{ Model } & \multicolumn{2}{|c|}{$\begin{array}{c}\text { Unstandardized } \\
\text { Coefficients } \\
\end{array}$} & \multirow{2}{*}{$\begin{array}{c}\begin{array}{c}\text { Standardized } \\
\text { Coefficients }\end{array} \\
\text { Beta }\end{array}$} & \multirow[t]{2}{*}{$\mathrm{t}$} & \multirow[t]{2}{*}{ Sig. } & \multicolumn{2}{|c|}{$\begin{array}{c}\text { Collinearity } \\
\text { Statistics }\end{array}$} \\
\hline & B & $\begin{array}{l}\text { Std. } \\
\text { Error }\end{array}$ & & & & Tolerance & VIF \\
\hline (Constant) & $-34,816$ & 11,250 & & $-3,095$ & ,003 & & \\
\hline DPK & ,818 & , 040 & ,920 & 20,213 & , 000 & ,709 & 1,410 \\
\hline
\end{tabular}


Jurnal Ekonomi dan Perbankan Syariah

Vol. 5. No.1, April 2017: 39-61, ISSN (cet): 2355-1755 | ISSN (online): 2579-6437

\begin{tabular}{llrrrrrrr}
$\mathbf{5 5}$ & \multicolumn{1}{l}{$\mathbf{5}$} & & & & & & & \\
1 & FDR &, 507 &, 111 &, 200 & 4,552 &, 000 &, 759 & 1,318 \\
& & & & & & & & \\
& ROA &,- 413 & 1,287 &,- 015 &,- 321 &, 749 &, 631 & 1,584 \\
& NPF &, 982 &, 833 &, 068 & 1,179 &, 244 &, 440 & 2,274 \\
& Inflasi &,- 381 &, 459 &,- 034 &,- 831 &, 410 &, 879 & 1,138 \\
\hline
\end{tabular}

a. Dependent Variable: Pembiayaan

Berdasarkan tabel 8 diatas, terlihat hasil pengujian hipotesis 2 bahwa variabel Dana Pihak Ketiga (DPK) terhadap variabel pembiayaan menunjukkan angka signifikansi sebesar 0,000 lebih kecil dari $\alpha=0,05$, sehingga hipotesis $\mathrm{Ha} 2$ diterima dan $\mathrm{H} 02$ ditolak, maka dapat dikatakan bahwa Dana Pihak Ketiga (DPK) berpengaruh signifikan terhadap Pembiayaan pada Bank Umum Syariah Devisa diIndonesia. Hasil penelitian ini mendukung Aristanti (2015), Yanis (2015), Huda (2014), Sari (2013), Arianti dan Muharam (2011), Rimadhani (2011), Andraeny (2011), dan Adnan (2005).

Bagi bank sebagai lembaga keuangan, dana diibaratkan sebagai darah dalam tubuh badan usaha dan menjadi hal yang sangat penting. Tanpa dana, aktifitas bank pasti akan sangat terganggu. Sumber dana yang dimiliki atau dikuasai oleh bank tidaklah hanya berasal dari milik bank itu sendiri, tetapi adapula sumber Dana Pihak Ketiga di mana Dana Pihak Ketiga ini merupakan sumber dana terpenting bagi kegiatan operasi bank dan merupakan ukuran keberhasilan bank jika mampu membiayai operasinya dari sumber dana ini (Rodoni, 2009).

Dana-dana yang dihimpun dari masyarakat (Dana Pihak Ketiga) ternyata merupakan sumber dana terbesar yang diandalkan oleh bank, mencapai $80 \%-90 \%$ dari seluruh dana yang dikelola oleh bank (Dendawijaya, 2005). Salah satu sumber dana yang dapat digunakan untuk pembiayaan adalah simpanan (salah satu unsur Dana Pihak Ketiga), sehingga semakin meningkat sumber dana (simpanan) yang ada, maka akan semakin besar juga bank dapat menyalurkan pembiayaan (Adnan, 2005).

Dengan demikian semakin besar sumber dana yang terkumpul, maka bank cenderung akan menyalurkan pembiayaan semakin besar pula. Hal tersebut dikarenakan salah satu tujuan bank adalah mendapatkan profit, sehingga bank tidak akan menganggurkan dananya begitu saja, dan cenderung menyalurkan dannya semaksimal mungkin guna memperoleh keutungan yang maksimal pula (Arianti,2010)

Hasil pengujian hipotesis 3 bahwa variabel Financing to Deposit Ratio (FDR) menunjukkan angka signifikansi sebesar 0,000 lebih kecil dari $\alpha=$ 0,05. Hal ini menunjukkan hipotesis Ha3 diterima dan H03 ditolak, sehingga dapat dikatakan Financing to Deposit Ratio (FDR) berpengaruh signifikan terhadap Pembiayaan pada Bank Umum Syariah Devisa di Indonesia. Hasil ini konsisten dengan hasil penelitian Yanis (2015), dan Prastanto (2012).

Rasio Financing to Deposit FDR dapat digunakan sebagai indikator untuk melihat kemampuan bank dalam menjalankan fungsi intermediasi 
secara baik, semakin tinggi rasio FDR maka bank tersebut akan semakin baik dalam menjalankan fungsi intermediasinya (Rachman, 2015). Jika FDR semakin besar maka semakin besar pula jumlah pembiayaan yang disalurkan oleh bank yang bersangkutan, hal ini sesuai dengan teori yang ada bahwa FDR menunjukkan tingkat kemampuan bank dalam menyalurkan Dana Pihak Ketiga yang dihimpun oleh bank yang bersangkutan.

Hasil pengujian hipotesis 4 bahwa variabel Return on Asset (ROA) menunjukkan angka signifikansi sebesar 0,749 lebih besar dari $\alpha=0,05$. Nilai koefisien beta yang dihasilkan $-0,413$. Hal ini menunjukkan hipotesis Ha4 ditolak dan H04 diterima, sehingga dapat dikatakan Return on Asset (ROA) tidak berpengaruh terhadap pembiayaan pada Bank Umum Syariah Devisa, konsisten dengan hasil penelitian Yanis (2015), Huda (2014), Widiyastuti (2013), dan Liliani dan Khairunnisa (2015)

Hasil penelitian ini tidak sesuai dengan teori yang menyatakan bahwa semakin besar tingkat keuntungan (ROA) yang didapat oleh bank, maka semakin besar pula upaya manajemen menginvestasikan keuntungan tersebut dengan berbagai kegiatan yang menguntungkan manajemen seperti kegiatan pembiayaan.

Penyebab perbedaan penelitian ini dengan teori yang ada, karena tidak konsistennya antara kenaikan atau penuruna ROA terhadap jumlah pembiayaan di setiap triwulannya pada tahun 2012, hal ini dapat dilihat pada data laporan keuangan di Bank Syariah Mandiri triwulan II 2012 ROA menunjukkan nilai sebesar $0,66 \%$ dengan total pembiayaan sebesar Rp 62,13 Miliar, dan pada triwulan III 2014 tingkat ROA meningkat menjadi 0,80\% akan tetapi total pembiayaan yang disalurkan menurun menjadi Rp 58,27 Miliar.

Hal demikianpun juga terjadi pada data laporan keuangan Bank Muamalat Indonesia dimana pada triwulan III 2012 terjadi penurunan ROA dari $1,68 \%$ menjadi $0,50 \%$ namun pada pembiayaan mengalami kenaikan dari Rp 39,16 Miliar menjadi Rp 41,36 Miliar. Dengan demikan berdasarkan hasil penelitian ini besarnya tingkat ROA belum tentu secara pasti akan turut meningkatkan jumlah pembiayaan yang disalurkan oleh BUS Devisa yang ada di Indonesia begitu pula sebaliknya.

Hasil pengujian hipotesis 5 bahwa variabel Non Performing Financing (NPF) menunjukkan angka signifikansi sebesar 0,244 lebih besar dari $\alpha=$

0,05. Hal ini menunjukkan hipotesis $\mathrm{H}_{5}$ ditolak dan $\mathrm{H}_{5}$ diterima, sehingga dapat dikatakan Non Performing Financing (NPF) tidak berpengaruh signifikan terhadap pembiayaan pada Bank Umum Syariah Devisa di Indonesia, hasil tersebut konsisten dengan hasil penelitian yang dilakukan oleh Aristantia (2015), Arianti dan Muharam (2011) dan Andreany (2011).

Hasil penelitian ini berbeda dengan teori yang mengatakan bahwa semakin tinggi tingkat NPF maka akan memberikan pengaruh yang negatif terhadap pembiayaan, yaitu berupa penurunan jumlah pembiayaan yang disalurkan dikarenakan semakin tinggi tingkat NPF. Perbedahan hasil penelitian dengan terori yang ada karena bank syariah saat ini lebih berhatihati dan lebih selektif dalam menyalurkan pembiayaan, dengan harapan 
Jurnal Ekonomi dan Perbankan Syariah

Vol. 5. No.1, April 2017: 39-61, ISSN (cet): 2355-1755 | ISSN (online): 2579-6437

$\mathbf{5 7}$

meminimalisir tingkat risiko penyaluran pembiayaan. Hal tersebut dapat disebabkan oleh tidak konsistennya antara peningkatan atau penurunan tingkat NPF terhadap jumlah pembiayaan yang disalurkan oleh BUS Devisa di setiap triwulannya pada laporan keuangan BUS Devisa.

Hal lain yang dapat menjadi penyebab tidak adanya pengaruh NPF terhadap pembiayaan yaitu berkaitan dengan regulasi bank terhadap pembiayaan bermasalah. Bank melakukan penanganan pembiayaan bermasalah khususnya pembiayaan yang diragukan atau macet oleh bank syariah banyak dilakukan dengan reschedulling, yaitu menjadwal kembali jangka waktu angsuran serta memperkecil jumlah angsuran. Reconditioning juga menjadi salah satu alternatif bank dalam menanganipembiayaan yang bermasalah, yaitu memperkecil margin keuntungan atau bagi hasil usaha, dan pengalihan atau pembiayaan ulang dalam bentuk pembiayaan al-qardhul hasan, yaitu mengangsur pengembalian pokok saja (tanpa tambahan margin) daripada melakukan eksekusi jaminan. Eksekusi jaminan dilakukan sebagai jalan terakhir bila cara lain yang lebih manusiawi (cara menurut ajaran islam) tidak berhasil mengatasi pembiayaan bermasalah (Muhammad, 2002).

Dengan demikian cara-cara tersebut menjadi semacam "pertahanan" bagi bank dalam mengatasi pembiayaan bermasalah, sehingga NPF yang tinggi tidak selalu menjadi penyebab naik atau turunnya jumlah pembiayaan yang disalurkan oleh bank, khususnya pada Bank Umum Syariah Devisa pada penelitian ini. Dengan demikian dapat disimpulkan dalam penelitian ini, naiknya tingkat NPF belum tentu secara pasti akan turut mengurangi jumlah pembiayaan yang disalurkan oleh BUS Devisa yang ada di Indonesia.

Hasil pengujian hipotesis 6 bahwa variabel Inflasi menunjukkan angka signifikansi sebesar 0,410 lebih besar dari $\alpha=0,05$. Nilai koefisien beta yang dihasilkan -0,381. Hal ini menunjukkan Ha6 ditolak dan H06 diterima, sehingga dapat dikatakan Inflasi tidak berpengaruh signifikan terhadap pembiayaan pada Bank Umum Syariah Devisa, hasil penelitian ini konsisten dengan penelitian Dahlan (2014), dan Hikmawan (2013), .

Inflasi pada dasarnya mencerminkan ketidakseimbangan sektor perekonomian masyarakat. Semakin tinggi inflasi cenderung memberikan efek penurunan pada pembiayaan. Hasil penelitian ini menunjukkan bahwa tidak terdapat pengaruh inflasi dengan pembiayaan. Hal tersebut disebabkan karena bank syariah memiliki daya tahan yang lebih kuat dibandingkan bank konvensional.

Krisis pertengahan tahun 1997 membuktikan tentang adanya kondisi menguntungkan bank syaiah (Hamidi, 2003). Saat perbankan nasional tengah tengah terjangkit virus negative spread dimana terjadi kerugian akibat bunga simpanan lebih tinggi dari bunga kredit tetapi bank syariah dengan prinsip bagi hasil justru beroperasi seperti biasa bahkan terlihat tanpa beban. Operasional bank syariah memiliki skema produk yang merujuk pada dua kategori kegiatan ekonomi yaitu produksi (profit sharing) dan distribusi (jual beli dan sewa menyewa).

Selain itu, dalam menjalankan operasionalnya mengganti sistem bunga dengan sistem bagi hasil, sehingga tidak membebani nasabah dalam 
pengembalian angsuran. Dengan demikian dapat disimpulkan bahwa besarnya tingkat inflasi tidak mempengaruhi jumlah penyaluran pembiayaan pada BUS Devisa di Indonesia.

\section{SIMPULAN}

Berdasarkan pada hasil analisis pembahasan yang telah dilakukan, maka dapat diperoleh kesimpulan sebagai berikut:

1. Variabel Dana Pihak Ketiga (DPK) dan Financing to Deposit Ratio (FDR) secara parsial berpengaruh secara signifikan terhadap Pembiayaan pada Bank Umum Syariah Devisa di Indonesia. Sedangkan variabel Return On Asset (ROA), Non PerformingFinancing (NPF) dan Inflasi secara parsial tidak berpengaruh terhadap Pembiayaan pada Bank Umum Syariah Devisa di Indonesia.

2. Variabel Dana Pihak Ketiga (DPK), Financing to Deposit Ratio (FDR), Return On Asset (ROA), Non Performing Financing (NPF) dan Inflasi secara simultan atau bersama-sama mempunyai pengaruh yang signifikan terhadap Pembiayaan pada Bank Umum Syariah Devisa di Indonesia.

3. Variabel bebas yang memberikan pengaruh yang kuat dan signifikan terhadap variabel terikat adalah Dana Pihak Ketiga (DPK). Pernyataan ini dapat dibuktikan dengan nilai koefesien regresi (B) sebesar 0,818 yang lebih besar dibandingan dengan koefisien regresi variabel Financing to Deposit Ratio (FDR) sebesar 0,507 .

\section{DAFTAR PUSTAKA}

Agista, A. R. (2015). Analisis Pengaruh DPK, CAR dan ROA terhadap Pembiayaan di PT Bank Mualamat Indonesia Tbk Periode 20072013. Naskah Publikasi, 2(2), 1-19.

Pratin, P., \& Adnan, A. (2005). Analisis Hubungan Simpanan, Modal Sendiri, NPL, Prosentase Bagi Hasil dan Markup Keuntungan Terhadap Pembiayaan Pada Perbankan Syariah Studi Kasus Pada Bank Muamalat Indonesia (BMI). Jurnal Sinergi.

Herdinigtyas, W., \& Almilia, L. S. (2006). Analisis Rasio CAMEL Terhadap Prediksi Kondisi Bermasalah Pada Lembaga Perbankan Perioda 20002002. Jurnal Akuntansi dan keuangan, 7(2), pp-131.

Andraeny, Dita. 2011. Analisis Pengaruh Dana Pihak Ketiga, TingkatBagi Hasil, dan Non Performing Financing Terhadap Volume Pembiayaan 
Jurnal Ekonomi dan Perbankan Syariah

Vol. 5. No.1, April 2017: 39-61, ISSN (cet): 2355-1755 | ISSN (online): 2579-6437

Berbasi Bagi Hasil Pada Perbankan Syariah Di Indonesia. Simposium Nasional Akuntansi XIV Aceh.

Pratami, W. A. N., \& Muharam, H. (2011). Analisis Pengaruh Dana Pihak Ketiga (Dpk), Capital Adequacy Ratio (Car), Non Performing Financing (Npf) Dan Return On Asset (Roa) Terhadap Pembiayaan Pada Perbankan Syariah (Studi Kasus Pada Bank Muamalat Indonesia Periode 2001-2011)(Doctoral dissertation, Universitas Diponegoro).

Bank Indonesia, Laporan Keuangan Publikasi Bank Umum Syariah UndangUndang No. 21 Tahun 2008 Tentang Perbankan Syariah

Dahlan, R. (2015). Pengaruh Tingkat Bonus Sertifikat Bank Indonesia Syariah dan Tingkat Inflasi Terhadap Pembiayaan Bank Syariah di Indonesia. ETIKONOMI: Jurnal Ekonomi, 13(2).

Dendawijaya, L. (2005). Manajemen Perbankan, Edisi Kedua, Cetakan. Kedua, Jakarta: Ghalia Indonesia, Bogor.

Direktorat Perbankan Syariah Bank Indonesia. Outlook Perbankan Syariah 2014. Jakarta, 2014.

Firaldi, Mufgi. (2013). Analisis Pengaruh Dari Dana Pihak Ketiga (DPK),Non Performing Financing (NPF) dan Tingkat Inflasi Terhadap Total Pembiayaan yang Diberikan Kepada Masyarakat oleh Bank Pembiayaan Rakyat Syariah (BPRS) Di Indonesia. Skripsi. Fakultas ekonomi Universitas Islam Negri Syarif Hidayatullah Jakarta.

Ghozali, I. (2011). Aplikasi Analisis Multivariate dengan Program IBM SPSS19. 0. Badan Penerbit Universitas Diponegoro, Semarang.

Gujarati, Damodar. (2003), Ekonometri Dasar. Terjemahan: Sumarno Zain, Jakarta: Erlangga.

Hikmawan, I. D. (2013). Faktor-Faktor Yang Mempengaruhi Volume Pembiayaan Berbasis Bagi Hasil Bank Umum Syariah (Doctoral dissertation, Universitas Sevelas Maret).

http://www.beritasatu.com/ekonomi/314843-pertumbuhan-bank-syariahmelambat-drastis-inipenyebabnya.html diakses pada 7 Februari 2016

https://id.wikipedia.org/wiki/Bank_devisa diakses pada 28 Mei 2016

Huda, G. F., \& PANGESTUTI, I. R. D. (2014). PENGARUH DPK, CAR, NPL DAN ROA TERHADAP PENYALURAN KREDIT (Studi Pada Bank Umum Yang Terdaftar Di Bursa Efek Indonesia Periode 2009. 2012) (Doctoral dissertation, Fakultas Ekonomika dan Bisnis).

Indriantoro dan Supomo. (1999). Metodologi Penelitian Bisnis untuk Akuntansi dan Manajemen. Edisi Pertama. BPFE Yogyakarta.Yogyakarta. 
60 | Umiyati\&Ana:Faktor-Faktor Yang Mempengaruhi Pembiayaan...

Laporan Bank Indonesia Statistika Perbankan Indonesia Laporan Bank Indonesia Statistika Perbankan Syariah

Liliani, dan Khairunnisa. (2015). Pengaruh Dana Pihak Ketiga (Dpk), NonPerforming Financing (Npf), Return On Asset (Roa), Dan Capital Adequacy Ratio (Car) Terhadap Pembiayaan Bagi Hasil Pada Bank Umum Syariah Di Indonesia Periode 2010-2013. Jurnal, Fakultas Ekonomi dan Bisnis, Universitas Telkom.

Hamidi, M Luthfi. (2003). Jejak-Jejak Ekonomi Islam. Jakarta: Abadi Publishing.

Maula, Khodijah Hadiyatul. (2008). Pengaruh Dana Pihak Ketiga, ModalSendiri, Marjin Keuntungan dan Non Performing Financing terhadap Pembiayaan Murabahah pada Bank Syariah Mandiri. Jurnal Ekonomi Keuangan dan Bisnis Islami, 4(1), 1-19

Muhamad. (2005). Bank Syariah Problema dan Prospek di Indonesia. Yogyakarta: Graha Ilmu.

Muhammad. (2002). Manajemen Pembiayaan Bank Syariah. Yogyakarta: UPP. AMM, YKPN.

Prastanto, P. (2013). FAKTOR YANG MEMPENGARUHI PEMBIAYAAN MURABAHAH PADA BANK UMUM SYARIAH DI INDONESIA. Accounting Analysis Journal, 2(1).

Pratami, Wuri N.P. 2011. Pengaruh DPK CAR NPF dan ROA Terhadap.Pembiayaan pada PT Bank Muamalat,Tbk. Jurnal Universitas Diponegoro. Semarang.

Rimadhani, M., \& Erza, O. (2011). Analisis Variabel-Variabel Yang Mempengaruhi Pembiayaan Murabahah Pada Bank Syariah Mandiri Periode 2008.01-2011.12. Media Ekonomi, 19(1), 27-52.

Heithzal, Rivai, dkk. (2007). Bank and Financial Institution Management Conventional \& Syaria System. Jakarta: PT. Raja GrafindoPersada

Rodoni, Ahmad. (2009). Investasi Syariah, Jakarta: UIN Jakarta.

Saekhu. (2015). Pengaruh Inflasi Terhadap Kinerja Pembiayaan BankSyariah, Volume Pasar Uang Antar Bank Syariah, Dan Posisi Outstanding Sertifikat Wadiah Bank

Sari, G. N. (2013). Faktor-faktor yang Mempengaruhi Penyaluran Kredit Bank Umum Di Indonesia (Periode 2008.1-2012.2). JURNAL RISET EKONOMI, MANAJEMEN, BISNIS DAN AKUNTANSI, 1(3).

Siregar, Sofyan. (2011). Statistika Deskriptif untuk penelitian. Jakarta: PT. Raja Grafindo Persada.

Sugiyono. (2009). Metode Penelitian Bisnis (Pendekatan Kuantitatif, Kualitatif, dan $R \& D)$. Bandung: Alfabeta. 
Jurnal Ekonomi dan Perbankan Syariah

Vol. 5. No.1, April 2017: 39-61, ISSN (cet): 2355-1755 | ISSN (online): 2579-6437

| 61

Suhardjono, (2003). Manajemen Perkreditan Usaha Kecil dan Menengah. Jakarta: UPP AMP YKPN.

Sukirno, Sadono. (2007). Makroekonomi Modern. Jakarta: PT Raja Grafindo.

Widiyastuti, W. (2013). Pengaruh Rasio Kinerja Keuangan Terhadap Penyaluran Pembiayaan Pada Perbankan Syariah Di Indonesia (Doctoral dissertation, UPN" Veteran" Yogyakarta).

www.bankmuamalat.co.id diakses pada 20 Mei 2016 www.bi.go.id diakses pada 2 Januari 2016 www.bnisyariah.co.id diakses pada 20 Mei 2016 www.dsnmui.or.id diakses pada 20 Februari 2016 www.ojk.go.id diakses pada 2 Januari 2016 www.syariahmandiri.co.id diakses pada 20 Mei 2016 www.datacon.co.id diakses pada 1 Februari 2016

Yanis, A. S. (2016). Faktor-Faktor Yang Mempengaruhi Pembiayaan Murabahah Pada Perbankan Syariah Di Indonesia. Jurnal Ilmu dan Riset Akuntansi, 4(8).

Rachman, Y. T., \& Apandi, A. (2015, August). PENGARUH FINANCING TO DEPOSIT RATIO (FDR), NON PERFORMING FINANCING (NPF), RETURN ON ASSETS (ROA), DAN CAPITAL ADEQUACY RATIO (CAR) TERHADAP PEMBIAYAAN MUDHARABAH (Survey Pada Bank Syariah Yang Listing Di Bursa Efek Indonesia Pada Tahun 2009-2013). International Conference and $\mathrm{Ph}$. D. Colloquium on Islamic Economics and Finance 2015 (ICIEF'15), Universitas Airlangga Department of Sharia Economics \& Universitas Mataram Faculty of Economics.

Arifin, Zainul . (2009). Dasar-Dasar Manajemen Bank Syariah. Jakarta: Azkia Publisher.

Zulifiah, F., \& Susilowibowo, J. (2014). Pengaruh Inflasi, BI Rate, Capital Adequacy Ratio (CAR), Nonperforming finance (NPF), Biaya Operasional dan Pendapatan Operasional (BOPO) terhadap Profitabilitas Bank Umum Syariah periode 2008-2012. Jurnal IlmuManajemen.. 
62 | Umiyati\&Ana:Faktor-Faktor Yang Mempengaruhi Pembiayaan... 